\title{
Analisis Morfologi dan Profil Protein Kedelai Varietas Grobogan Hasil Iradiasi Pada Kondisi Cekaman Genangan
}

\author{
Dianita Indahsari dan Triono Bagus Saputro \\ Departemen Biologi, Fakultas Ilmu Alam, Institut Teknologi Sepuluh Nopember (ITS) \\ e-mail: trionobsaputro@bio.its.ac.id
}

\begin{abstract}
Abstrak-Kedelai (Glycine max) merupakan tanaman pangan terpenting ketiga setelah padi dan jagung. Akan tetapi, produktivitas menurun karena kedelai sensitif terhadap genangan. Sehingga diperlukan perakitan varietas unggul yang tahan cekaman genangan dengan memanfaatkan iradiasi sinar gamma. Penelitian ini bertujuan untuk mengetahui morfologi dan profil protein tanaman kedelai varietas Grobogan yang diberikan perlakuan iradiasi pada kondisi cekaman genangan. Iradiasi menggunakan sinar gamma dengan dosis 0 Gy, 25 Gy, 50 Gy, 75 Gy, dan 100 Gy. Varian iradiasi diseleksi pada kondisi tergenang dengan konsentrasi $0 \%, 100 \%, 150 \%, 200 \%$, dan $250 \%$. Pengamatan morfologi meliputi viabilitas dan vigoritas benih, tinggi tanaman, dan luas daun. Analisis profil protein dengan SDS-PAGE. Berdasarkan hasil penelitian dapat disimpulkan bahwa dosis iradiasi dan konsentrasi genangan memberikan respon yang berbeda-beda pada setiap perlakuan. Pengamatan morfologi dengan parameter viabilitas dan vigoritas benih, tinggi tanaman, dan luas daun paling optimal saat diberikan dosis iradiasi 0 Gy, 25 Gy, dan 50 Gy dengan konsentrasi genangan kontrol. Sedangkan terendah saat diberikan dosis iradiasi 75 Gy dan 100 Gy dengan konsentrasi genangan $250 \%$. Analisis profil protein dengan SDS-PAGE didapatkan bahwa pita protein dengan mobilitas terendah sampai tertinggi terletak pada berat molekul 260-11 kDa. Hal tersebut ditunjukkan dengan perbedaan jumlah pita protein, berat molekul pita protein, dan ketebalan pita protein yang dihasilkan.
\end{abstract}

Kata Kunci- Genangan, Iradiasi, Kedelai.

\section{PENDAHULUAN}

$\mathrm{K}$ EDELAI (Glycine max) merupakan tanaman pangan terpenting ketiga setelah padi dan jagung [1]. Kedelai mengandung sekitar $20 \%$ minyak berdasarkan bahan kering dengan $30-50 \%$ protein. Kedelai juga memiliki profil asam amino yang superior dan proteinnya memiliki potensi besar sebagai sumber utama protein makanan [2]. Produksi kedelai di dalam negeri hanya mampu memenuhi sekitar 65,61\% konsumsi domestik yang menyebabkan impor [3]. Penurunan produktivitas dikarenakan kedelai sangat sensitif terhadap genangan [4].

Cekaman genangan didefinisikan ketika pori-pori tanah jenuh dengan air sehingga menjadi lebih dari kapasitas tanah paling tidak 20\% [5]. Kekurangan oksigen dalam tanah akibat genangan merupakan faktor pembatas pertumbuhan dan produktivitas tanaman [6]. Kekurangan $\mathrm{O}_{2}$ mempengaruhi permeabilitas membran sel, hubungan air-tanaman, nutrisi mineral, produksi zat pengatur tumbuh dan alokasinya, fotosintesis, respirasi dan alokasi karbohidrat [7]. Perakitan varietas unggul merupakan solusi yang tepat dikarenakan karakternya yang stabil pada kondisi lingkungan yang tidak menguntungkan. Perakitan varietas unggul memerlukan tetua sebagai sumber gen ketahanan terhadap genangan. Saat ini belum tersedia sumber gen ketahanan terhadap genangan pada tanaman kedelai, sehingga perlu dilakukan induksi variasi menggunakan sinar gamma.

Iradiasi sinar gamma merupakan salah satu cara dalam meningkatkan keragaman genetik tanaman. Perubahan genetik hasil iradiasi bersifat acak sehingga diperlukan seleksi varian secara terarah. Seleksi dilakukan untuk memperoleh tanaman dengan sifat yang diinginkan, seperti toleran cekaman genangan. Dalam penelitian ini digunakan kedelai varietas Grobogan. Varietas Grobogan merupakan varietas unggul yang berumur genjah dan berproduktivitas lebih dari 2,5 t/ha [8].

Penelitian ini bertujuan untuk mengetahui morfologi dan profil protein tanaman kedelai varietas Grobogan yang diberikan perlakuan iradiasi pada kondisi cekaman genangan.

\section{METODOLOGI}

\section{A. Waktu dan Tempat Penelitian}

Penelitian dilaksanakan pada bulan Januari-Juni 2018. Iradiasi dengan menggunakan sinar Gamma dilakukan di BATAN. Pengamatan morfologi dilakukan di greenhouse dan Laboratorium Biosains dan Teknologi Tumbuhan, Departemen Biologi, ITS, Surabaya. Analisis profil protein dilakukan di Laboratorium Rumah Sakit Khusus Infeksi (RSKI), UNAIR, Surabaya.

\section{B. Prosedur Kerja}

Penelitian dilakukan sesuai dengan metode sebagai berikut:

1) Pengukuran Kapasitas Lapang Media Tanah

Pengukuran kapasitas lapang bertujuan untuk menentukan volume penyiraman sebagai patokan pemberian taraf penggenangan yaitu dengan cara media tanam dalam polybag disiram dengan air sampai menetes (jenuh) kemudian didiamkan selama 3 hari sampai tidak ada air yang menetes. Selanjutnya, media tanam ditimbang berat basah dan berat keringnya. Berat basah ditimbang setelah tidak ada air yang 
menetes dari polybag. Berat kering ditimbang setelah media tanam dioven pada suhu $105{ }^{\circ} \mathrm{C}$ sampai diperoleh berat konstan.

Kebutuhan air berdasarkan kapasitas lapangnya dihitung dengan rumus sebagai berikut:

Keterangan:

$$
\mathrm{KL}(\%)=\frac{T b-T k}{T k} \times 100 \%
$$

KL : Kapasitas Lapang

$\mathrm{Tb}:$ Berat Basah Tanah

Tk : Berat Kering Tanah

2) Iradiasi Benih

Biji kedelai varietas Grobogan diperoleh dari Balai Penelitian Tanaman Kacang-kacangan dan Umbi-umbian (BALITKABI), Kendal Payak-Malang. Sebanyak 500 biji kedelai direndam pada larutan etanol $70 \%$ selama 15 menit. Kemudian dilanjutkan dengan melakukan perendaman pada larutan $\mathrm{NaOCl} 1 \%$ selama 2 menit. Selanjutnya biji diletakkan pada cawan petri dan diwrapping untuk menghindari kontaminasi. Kemudian dilakukan pemaparan sinar Gamma pada beberapa level yaitu $0 \mathrm{~Gy}, 25 \mathrm{~Gy}, 50 \mathrm{~Gy}, 75 \mathrm{~Gy}$, dan 100 Gy yang dilakukan di Badan Teknologi Atom Nasional (BATAN).

3) Penyemaian Benih

Biji kedelai yang telah dipapar sinar Gamma ditanam pada media yang telah disiapkan untuk proses penyemaian. Bahan yang digunakan meliputi media tanam siap digunakan, air dan potray. Alat yang digunakan meliputi sekop, bak, dan timbangan.

Langkah yang dilakukan adalah biji kedelai varietas Grobogan hasil iradiasi direndam selama 2 jam menggunakan aquades kemudian ditiriskan. Hal ini bertujuan untuk mempercepat proses imbibisi sehingga pertumbuhan tunas akan berlangsung lebih cepat. Biji yang telah direndam dan ditiriskan selanjutnya ditumbuhkan di potray berisi media tanam kemudian disemai hingga muncul 2 daun.

4) Uji Viabilitas dan Vigoritas Benih

Viabilitas benih merupakan salah satu unsur dalam mutu fisiologis benih. Viabilitas dapat dilihat dari daya berkecambah. Daya berkecambah menginformasikan kemungkinan benih tumbuh normal pada kondisi lapang dan lingkungan yang optimum [9]. Parameter viabilitas yang diamati dalam penelitian ini yaitu daya berkecambah (DB) dan laju perkecambahan (LP).

Daya berkecambah (DB) yaitu banyaknya persentase kecambah normal pada pengamatan selama 7 hari setelah tanam (hst), dengan rumus sebagai berikut:

$$
\mathrm{DB}=\frac{\text { Jumilah kecambah normal }}{\text { jumlah benih yang ditanam }} \times 100 \%
$$

Laju perkecambahan (LP) ditentukan dengan menghitung jumlah hari yang diperlukan untuk munculnya radikel atau plumula selama jangka waktu tertentu (7 hari), dengan rumus sebagai berikut:

$$
\mathrm{LP}=\frac{N_{1} T_{1}+N_{2} T_{2}+\ldots+N_{x} T_{x}}{\text { Iumlah total benih yang berkecambah }}
$$

Keterangan:

LP : laju perkecambahan
$\mathrm{N}$ : jumlah benih yang berkecambah pada satuan waktu tertentu

$\mathrm{T}$ : jumlah waktu antara awal pengujian sampai dengan akhir dari interval tertentu suatu pengamatan

Vigor benih adalah kemampuan benih tumbuh normal pada kondisi lapang dan lingkungan suboptimum. Benih yang vigor mampu tumbuh pada berbagai macam kondisi di lapangan [9]. Parameter vigoritas yang diamati dalam penelitian ini yaitu keserempakan tumbuh (KST).

Keserempakan tumbuh benih dihitung dengan menggunakan persentase kecambah normal kuat (hari ke-4), dengan rumus sebagai berikut:

$$
\mathrm{KST}=\frac{K K}{T B} \times 100 \%
$$

Keterangan:

KST : keserampakan tumbuh

KK : jumlah kecambah kuat

TB : total benih yang dianalisis

\section{5) Tahap Aklimatisasi}

Pembuatan media tanam dilakukan dengan menyiapkan tanah taman dan pupuk organik. Setiap polybag memiliki komposisi $1,5 \mathrm{~kg}$ tanah taman dan $0,5 \mathrm{~kg}$ pupuk organik sehingga didapatkan berat total sebanyak $2 \mathrm{~kg} /$ polybag. Media tanam yang telah ditimbang diaduk secara merata untuk selanjutnya dimasukkan kedalam polybag dan diatur di rak greenhouse sesuai dengan lay out percobaan. Selanjutnya setiap polybag diberi label sesuai perlakuan.

Proses aklimatisasi tanaman kedelai (Glycine max) dilakukan selama 10 hari. Aklimatisasi bertujuan untuk adaptasi tanaman kedelai (Glycine max) terhadap media baru. Pemeliharaan yang dilakukan adalah penyiraman. Penyiraman dilakukan pada saat proses penyemaian dan aklimatisasi secara teratur pada pagi dan sore hari sesuai kebutuhan.

\section{6) Tahap Seleksi Genangan}

Perlakuan cekaman genangan dilakukan di greenhouse, Departemen Biologi, ITS. Tanaman kedelai yang telah diaklimatisasi selama 14 hari selanjutnya diberi perlakuan cekaman genangan sesuai perhitungan kapasitas lapang yang diperoleh.

Penggenangan dilakukan selama 14 hari pada semua taraf perlakuan dengan cara memberikan air ke dalam masingmasing polybag sebanyak konsentrasi yang telah ditentukan berdasar pada hasil kapasitas lapang, setelah itu diberikan penyangga bambu pada masing-masing polybag yang berfungsi untuk menyangga tanaman karena struktur tanah yang jenuh air. Kemudian diukur tinggi genangan menggunakan penggaris sebagai ukuran dalam penambahan air setiap harinya.

\section{7) Pengamatan Pertumbuhan Tanaman Kedelai (Glycine} max)

Pemanenan tanaman kedelai dilakukan setelah 14 hari perlakuan cekaman genangan. Tanaman pada tiap-tiap perlakuan diambil dan dibersihkan dari sisa tanah menggunakan air kemudian dikeringanginkan. Selanjutnya, tanaman dimasukkan ke dalam plastik ziplock dan diberi label. Kemudian disimpan dalam freezer untuk selanjutnya di lakukan analisis. 
a. Tinggi Tanaman

Pengukuran terhadap tinggi tanaman dilakukan sebelum dan sesudah masa perlakuan cekaman genangan. Tanaman kedelai diukur dari pangkal batang sampai ujung batang atau titik tumbuh.

\section{b. Luas Daun}

Pengukuran terhadap luas daun dilakukan setelah proses pemberian cekaman genangan selama 14 hari dengan metode gravimetri, yaitu dengan cara menggambar daun yang akan ditaksir luasnya pada selembar kertas. Luas daun dihitung berdasarkan perbandingan berat replika daun dengan berat total kertas. Sampel daun yang digunakan diambil dari bagian atas, tengah, dan bawah tanaman pada tiap perlakuan. Adapun rumus perhitungannya adalah sebagai berikut:

Keterangan:

$$
\mathrm{LD}=\frac{W r}{W t} \times \mathrm{LK}
$$

$\mathrm{LD}=$ luas daun

$\mathrm{Wr}=$ berat kertas replika daun $(\mathrm{g})$

$\mathrm{Wt}=$ berat total kertas $(\mathrm{g})$

$\mathrm{LK}=$ luas total kertas $(\mathrm{cm})$

8) Uji Profil Protein

Metode isolasi protein mengacu pada penelitian [10], yakni sebagai berikut: daun tanaman kedelai berumur 30 hari dipanen sebelum dan sesudah perlakuan cekaman genangan. Daun ditimbang sebanyak 0,1 gram dan dimasukkan microtube steril. Setelah itu, ditambahkan $300 \mu \mathrm{L}$ larutan PBS $1 \times$ kemudian digerus dengan pellet pestle hingga homogen. Homogenat disentrifus dengan suhu $4^{\circ} \mathrm{C}$ kecepatan $5000 \mathrm{rpm}$ selama 5 menit. Supernatan diambil dan dipindahkan ke dalam microtube steril yang baru dan disimpan pada suhu $4^{\circ} \mathrm{C}$.

Supernatan yang didapat mengandung banyak protein, karena komposisi yang heterogen maka protein tersebut perlu dipisahkan untuk dilihat profilnya. Profil protein tanaman diamati untuk mengetahui apakah tanaman tersebut berhasil memproduksi protein yang berperan pada saat cekaman atau tidak. Terlebih dahulu dibuat sample buffer (loading buffer), running buffer (buffer electrode), staining solution, dan destaining solution. Kemudian pembuatan gel SDS-PAGE, persiapan gel SDS-PAGE, running sampel, staining dan destaining gel.

Prosedur pembuatan gel SDS-PAGE yaitu short plate diletakkan di atas spacer plate dan diisolasi pada bagian bawah, sisi kanan, dan sisi kiri. Kemudian cams ditekan dalam posisi terbuka pada casting frame. Kedua plates dimasukkan ke dalam casting frame dengan menempatkan short plate pada bagian depan. Kunci cams dengan ditekan untuk mengamankan glass plates. Casting frame diamankan pada casting stand dengan menarik tuas pegas. Aquades steril dimasukkan pada glass plates untuk memastikan tidak ada kebocoran. Dibersihkan glass plates yang sudah dituang aquades steril dengan kertas saring. Separating gel 10\% dibuat dan dituang ke glass plates. Segera dituang 2-propanol hingga penuh untuk meluruskan garis separating gel. Ditunggu beberapa saat hingga separating gel memadat. Glass plates dibersihkan dari 2-propanol dengan kertas saring. Stacking gel 5\% dibuat dan dituang ke glass plates hingga penuh. Kemudian beri comb antara glass plates sebelum stacking gel memadat.
Persiapan gel SDS-PAGE dilakukan dengan cara gel cassette sandwich dilepaskan dari casting frame. Kemudian gel cassette sandwich dimasukkan ke dalam electrode assembly dengan short plate menghadap ke dalam. Kedua tuas cams ditutup dari electrode assembly. Inner chamber diturunkan ke dalam mini tank. Running buffer (buffer electrode) dituang pada inner chamber sampai level mencapai setengah di antara bagian atas glass plates yang lebih tinggi dan lebih pendek dari gel cassettes dan lower buffer chamber sampai batas garis 2 gels. Comb secara perlahan diambil dari glass plates agar terlihat sumuran gel.

Langkah selanjutnya yaitu running sampel. Disiapkan sampel protein sebanyak $40 \mu \mathrm{L}$ yang ditambahkan $10 \mu \mathrm{L}$ sample buffer pada microtube steril. Sampel dipanaskan dengan dry block heating thermostat dengan suhu $100^{\circ} \mathrm{C}$ selama 2 menit dan di freezer pada suhu $-20^{\circ} \mathrm{C}$ selama 15 menit. Sementara menunggu, disiapkan $7 \mu \mathrm{L}$ marker (spectra multicolor broad range protein ladder) yang ditambahkan 10 $\mu \mathrm{L}$ sample buffer pada microtube steril. Sebanyak $20 \mu \mathrm{L}$ marker dan sampel dimasukkan pada sumuran gel elektroforesis dengan menggunakan sample loading guide. Proses running dilakukan dengan menggunakan tenaga 150 volt, $50 \mathrm{~mA}$ selama 2 jam. Proses running dihentikan apabila loading dye mendekati batas bawah dari lembaran gel.

Proses elektroforesis selesai maka dilakukan staining dan destaining gel. Langkah-langkah yang dilakukan adalah tutup tangki dilepas dan diangkat inner chamber assembly dengan hati-hati. Running buffer (buffer electrode) dituang dari inner chamber assembly dan dibuang. Dibuka cams dan dikeluarkan gel cassette sandwich dari electrode assembly. Isolasi yang masih menempel pada gel cassette sandwich dibuang. Gel cassette sandwich dibuka perlahan dengan plastic gel releaser. Gel dikeluarkan dari glass plates dengan cara mengapungkannya pada $\mathrm{ddH}_{2} \mathrm{O}$ dengan dibalik. Electrode assembly dan mini tank segera bilas dengan aquades steril. Lembaran gel dimasukkan pada cawan Petri untuk siap di staining selama 24 jam. Pada proses staining akan didapatkan hasil berupa lembaran gel berwarna biru sehingga perlu dilakukan didestaining untuk menghilangkan warna biru, namun pita-pita hasil running pada lembaran gel agar tetap dipertahankan berwarna biru. Hasil staining pada lembaran gel dibilas dengan destaining solution selama 2 jam. Kemudian destaining solution dibuang dan telihat pita-pita berwarna biru hasil running pada lembaran gel.

\section{Rancangan Penelitian}

Percobaan menggunakan Rancangan Acak Lengkap (RAL) satu faktor dengan 3 ulangan. Faktor tersebut adalah penggenangan dengan 4 taraf perlakuan yaitu:

G0 $=$ Tanpa genangan (kontrol)

$\mathrm{G} 1=$ Genangan $100 \%$

$\mathrm{G} 2=$ Genangan $150 \%$

$\mathrm{G} 3=$ Genangan $200 \%$

$\mathrm{G} 4=$ Genangan $250 \%$

\section{Analisis Data}

Analisis pertumbuhan tanaman dianalisis secara statistik menggunakan analisis keragaman (ANOVA) two-way taraf 
signifikan $(\alpha) \quad 0,05 \%$ untuk mengetahui pengaruh perlakuan pada parameter yang diamati. Hipotesis yang digunakan adalah sebagai berikut:

$\mathrm{H}_{0}$ : Genangan tidak berpengaruh terhadap morfo-fisiologi kedelai (Glycine max) varietas Grobogan.

$\mathrm{H}_{1}$ : Genangan berpengaruh terhadap morfo-fisiologi kedelai (Glycine max) varietas Grobogan.

Selanjutnya, apabila $\mathrm{H}_{1}$ diterima maka dilakukan uji lanjutan yaitu uji Duncan Multiple Range Test (DMRT) 5\% dengan program IBM SPSS Statistics Version 23 untuk membandingkan perlakuan genangan yang paling efektif diantara tiap-tiap perlakuan.

\section{HASIL DAN PEMBAHASAN}

\section{A. Viabilitas dan Vigoritas Benih Kedelai}

Peningkatan produktivitas dapat diupayakan sejak dari tingkat benih yaitu melalui peningkatan viabilitas dan vigor benih. Viabilitas dan vigor benih menentukan mutu benih yang digunakan, yaitu mutu fisik dan fisiologi benih. Perbaikan mutu benih dapat dilakukan dengan memanfaatkan teknik iradiasi sinar gamma, yaitu dapat meningkatkan viabilitas dan vigor benih. Pemanfaatan teknik iradiasi sinar gamma digunakan sebagai seed treatment [11]. Pengukuran viabilitas dan vigoritas benih pada penelitian ini dilakukan sesudah penyemaian untuk mengetahui pengaruh faktor dosis iradiasi terhadap viabilitas dan vigoritas benih.

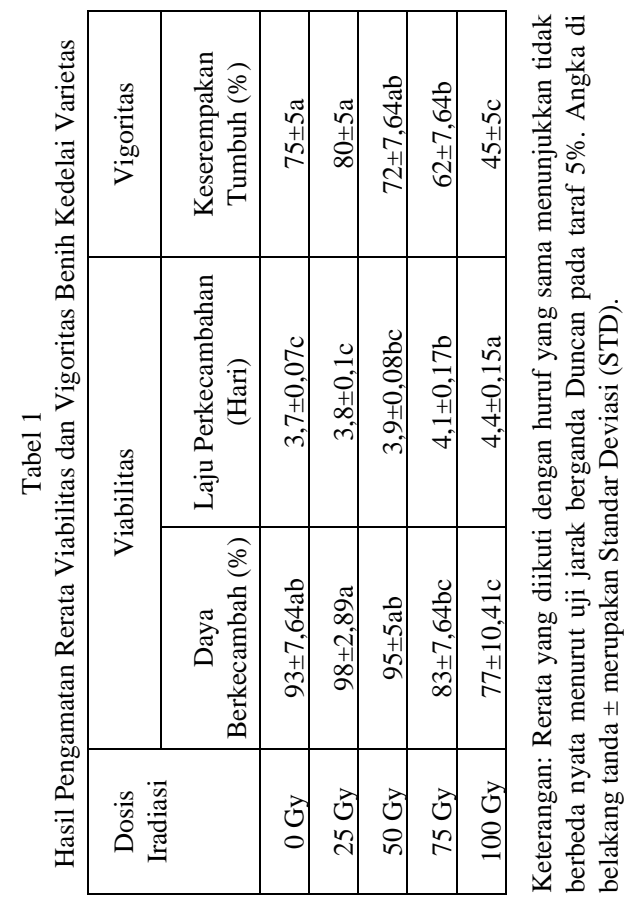

Berdasarkan Tabel 1 diketahui bahwa dosis iradiasi paling optimal berdasarkan parameter daya berkecambah (DB) dan keserempakan tumbuh (KST) adalah 25 Gy. Sedangkan dosis iradiasi paling optimal berdasarkan parameter laju perkecambahan (LP) adalah 0 Gy. Hal ini dikarenakan iradiasi dengan dosis rendah umumnya menghasilkan pengaruh stimulasi terhadap perkecambahan melalui peningkatan aktivitas enzim, perbaikan sel-sel respirasi dan meningkatkan produksi struktur reproduksi [12]. Penambahan dosis iradiasi menunjukkan bahwa perkecambahan biji dapat ditingkatkan dengan iradiasi dosis rendah, dimana iradiasi dosis tinggi dapat menghambat perkecambahan dan berkorelasi secara langsung dengan laju perkecambahan [13] [14]. Benih yang mempunyai keserempakan tumbuh yang tinggi memiliki tingkat vigor yang tinggi. Benih yang vigornya baik/tinggi yaitu benih yang cepat tumbuhnya dan serempak/seragam, karena benih yang cepat tumbuhnya dan serempak mengindikasikan bahwa benih tersebut mampu untuk beradaptasi dengan keadaan lingkungan. Keserempakan tumbuh mengindikasikan vigor daya simpan. Artinya bahwa keserempakan tumbuh yang tinggi mengindikasikan daya simpan kelompok benih yang tinggi pula. Ketidakserempakkan tumbuh dapat diakibatkan oleh sifat genetik yang tidak sama, atau oleh kondisi lingkungan yang tidak homogen [15].

Dosis iradiasi 100 Gy memberikan respon daya berkecambah (DB), laju perkecambahan (LP), dan keserempakan tumbuh (KST) terendah. Hal ini dikarenakan iradiasi sinar gamma dalam dosis yang tinggi umumnya menghasilkan pengaruh inhibitor terhadap perkecambahan, menurunnya kadar auksin atau kerusakan kromosom [12]. Penurunan laju perkecambahan pada kedelai disebabkan akibat pemberian iradiasi sinar gamma, hal ini memicu penurunan pembelahan sel, sintesis hormon, terganggunya transportasi nutrisi keseluruh bagian tanaman, dan adanya gangguan metabolisme pada apikal meristem [16][17]. Selain itu adanya efek deterministik yaitu efek yang disebabkan karena kematian sel akibat paparan iradiasi. Efek deterministik timbul bila dosis yang diterima tanaman di atas dosis ambang (threshold dose) dan umumnya timbul beberapa saat setelah iradiasi [18]. Ketidakmampuan biji untuk berkecambah pada dosis sinar gamma yang lebih tinggi telah dikaitkan dengan beberapa alasan: (i) banyak perubahan histologis dan sitologi; (ii) gangguan dan disorganisasi tunika atau lapisan biji yang berbanding lurus dengan intensitas paparan sinar gamma; (iii) gangguan mitosis atau eliminasi virtual pembelahan sel di zona meristematik selama perkecambahan. Penghambatan perkecambahan benih dan pertumbuhan benih yang diberikan oleh iradiasi sering dianggap berasal dari pembentukan radikal bebas pada biji yang diiradiasi [19].

\section{B. Tinggi Tanaman Kedelai}

Tinggi tanaman merupakan sifat kuantitatif yang dikendalikan oleh banyak gen. Karakter tinggi tanaman atau penurunan tinggi tanaman merupakan indikator yang paling umum yang digunakan untuk melihat efek mutagen [20]. Pengukuran tinggi tanaman pada penelitian ini dilakukan sebelum dan sesudah cekaman genangan untuk mengetahui pengaruh faktor dosis iradiasi, faktor konsentrasi genangan, dan interaksi antara faktor dosis iradiasi dan konsentrasi genangan terhadap pertumbuhan tinggi tanaman. 


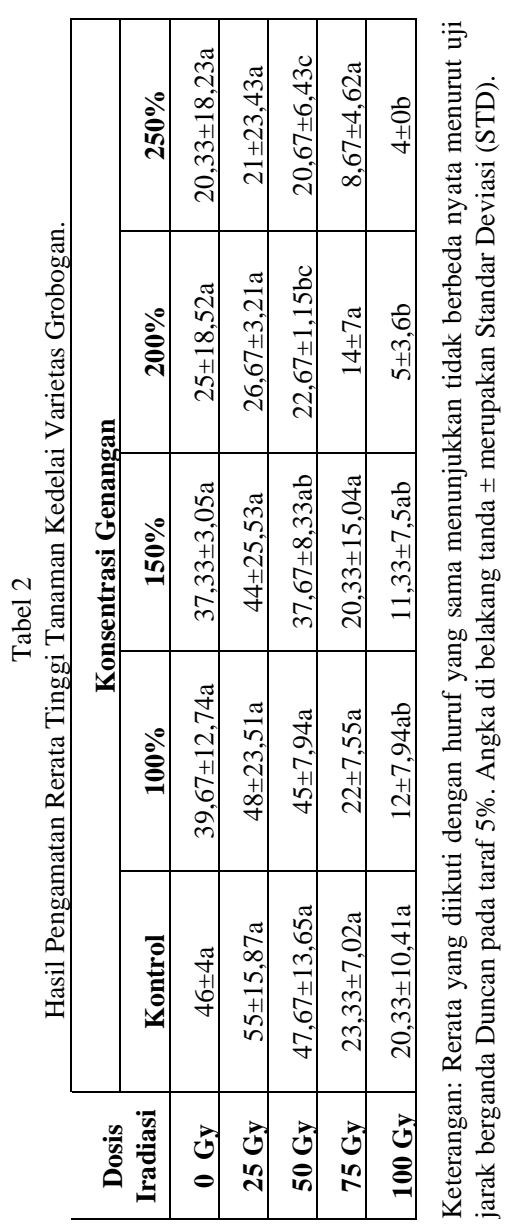

Berdasarkan Tabel 2 diketahui bahwa dosis iradiasi 25 Gy dengan konsentrasi genangan kontrol efektif dalam meningkatkan pertumbuhan tinggi tanaman. Hal ini dikarenakan iradiasi dosis rendah akan menginduksi stimulasi pertumbuhan dengan mengubah jaringan sinyal hormonal dalam sel tanaman atau dengan meningkatkan kapasitas anti oksidatif sel [21]. Sedangkan dosis iradiasi 100 Gy dengan konsentrasi genangan $250 \%$ memperlambat pertumbuhan tinggi tanaman. Penurunan tinggi tanaman atau tanaman menjadi kerdil karena pengaruh dosis yang tinggi akibatnya adanya gangguan fisiologis atau kerusakan kromosom yang diakibatkan oleh mutagen (radiasi sinar gamma) yang diberikan. Pemberian dosis yang terlalu tinggi akan menghambat pembelahan sel yang menyebabkan kematian sel yang berpengaruh terhadap proses pertumbuhan tanaman. Tetapi dosis iradiasi yang terlalu rendah tidak cukup untuk memutasi tanaman karena frekuensi mutasi yang terlalu rendah hanya menghasilkan sedikit sektor yang termutasi [20]. Iradiasi sinar gamma menyebabkan terjadinya mutasi secara acak mengakibatkan kerusakan fisiologis dalam metabolisme perkembangan sel, sehingga potensi pertumbuhan tanaman dapat lebih cepat atau lebih lambat [22]. Etilen merupakan salah satu hormon yang menstimulus adanya percepatan pemanjangan sel saat tanaman berada dalam kondisi tergenang [23][24]. Fungsi etilen tidak hanya berperan dalam elongasi sel tetapi juga pembelahan sel [24] [25]. Elongasi batang tanaman disebabkan oleh interaksi antara giberelin (GA) dan etilen. Proses elongasi tercepat pada ruas diproduksi oleh etilen yang menginduksi rasio spesifik antara giberelin (GA) dan asam absisat (ABA). Genangan menurunkan ABA alami dan meningkatkan GA [26] [27]. Penggenangan yang lebih lama akan mengurangi tinggi tanaman [7].

\section{Luas Daun}

Daun merupakan salah satu organ tanaman yang penting, karena pada daun terdapat bagian/komponen dan sekaligus tempat berlangsungnya proses fotosintesis dan transpirasi yang menentukan pertumbuhan tanaman. Oleh karena itu luas daun merupakan salah satu parameter penting dalam analisis pertumbuhan tanaman [28]. Pengukuran luas daun pada penelitian ini dilakukan sesudah cekaman genangan untuk mengetahui pengaruh faktor dosis iradiasi, faktor konsentrasi genangan, dan interaksi antara faktor dosis iradiasi dan konsentrasi genangan terhadap luas daun.

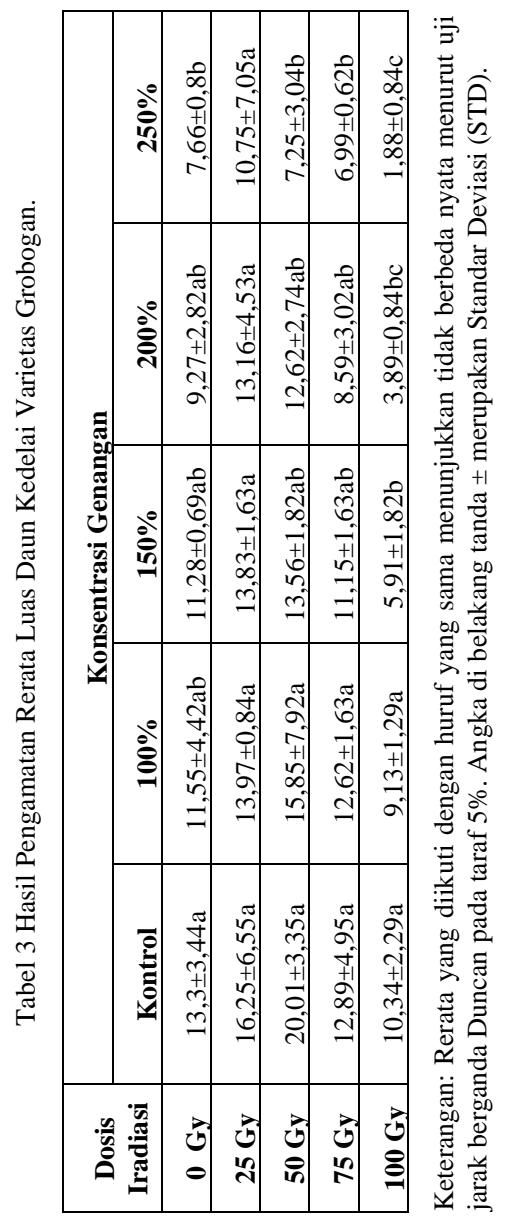

Berdasarkan Tabel 3 diketahui bahwa dosis iradiasi 50 Gy dengan konsentrasi genangan kontrol efektif dalam meningkatkan luas daun. Sedangkan dosis iradiasi 100 Gy dengan konsentrasi genangan $250 \%$ menurunkan luas daun. Hal ini dikarenakan iradiasi menyebabkan susunan genetik tanaman yang berkaitan dengan luas daun menjadi berubah [29]. ANR daun yang tinggi pada tanaman yang toleran genangan menunjukkan efisiensi pemanfaatan nitrat oleh 
tanaman. Selain itu, dalam keadaan tergenang, reduksi nitrat menjadi nitrit dapat berperan sebagai alternatif transfer elektron untuk mengganti peran oksigen [7]. Organ tanaman yang aktif melakukan fotosintesis adalah daun, oleh karena itu semakin besar luas daun maka hasil fotosintesis atau fotosintat akan meningkat yang dapat ditampung dalam bentuk buah, polong atau biji [30].

\section{Profil Protein}

Protein terkait dengan fungsi utama organ, secara khusus diekspresikan dalam organ/jaringan spesifik. Organ spesifik ini mengekspresikan protein sehingga penting untuk pertumbuhan dan perkembangan tanaman [31]. Pada tumbuhan tingkat tinggi, akar adalah salah satu organ indera utama untuk mendeteksi kondisi stres di dalam tanah, dan merupakan organ pertama yang terkena dampak karena stres ini. Bagian-bagian aerial tumbuhan merasakan adanya stres akar melalui mekanisme pensinyalan sistemik yang melibatkan kehilangan atau dapat mengirimkan zat aktif fisiologis dari akar ke tunas. Identifikasi gen atau protein yang terlibat dalam respon stres biotik atau abiotik adalah langkah mendasar dalam memahami mekanisme molekuler respons stres dan mengembangkan tanaman transgenik dengan toleransi yang lebih baik terhadap stres [32].

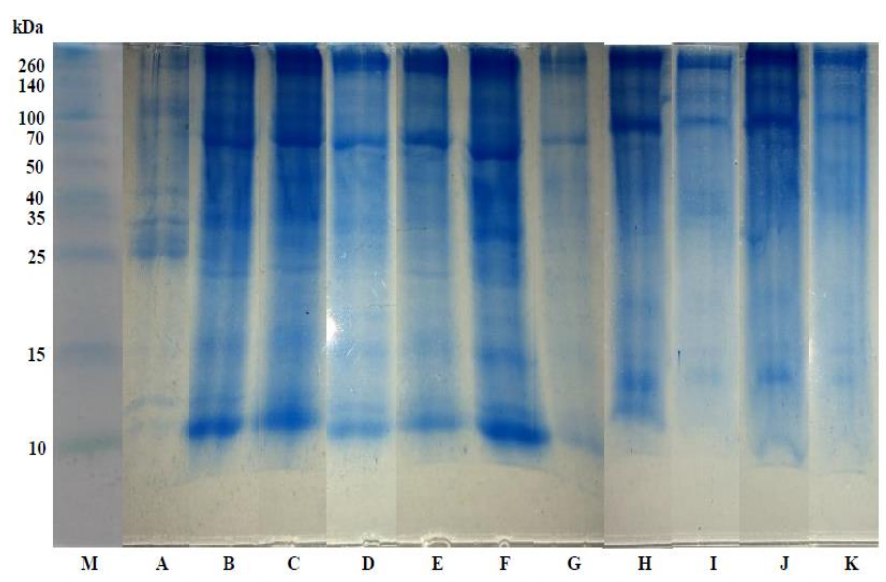

Gambar 1. Hasil Analisis Profil Protein Kedelai Varietas Grobogan dengan SDS-PAGE.

Keterangan : $\mathrm{M}=$ Marker; $\mathrm{A}=0 \mathrm{~Gy}$ (kontrol) (sebelum genangan) ; $\mathrm{B}=0 \mathrm{~Gy}$ (kontrol); $\mathrm{C}=0$ Gy (250\%); D = 25 Gy (kontrol); $\mathrm{E}=25 \mathrm{~Gy}(250 \%) ; \mathrm{F}=50$ Gy (kontrol); G = 50 Gy (250\%); H = 75 Gy (kontrol); I = 75 Gy (250\%); J = 100 Gy (kontrol); K = 100 Gy (250\%).

Berdasarkan Gambar 1 menunjukkan bahwa perbedaan profil protein dapat dilihat berdasarkan keberadaan pita-pita protein dan variasi berat molekul protein. Pada dosis iradiasi 0 Gy dan 50 Gy dengan konsentrasi genangan kontrol (sesudah genangan) ditemukan 8 pita protein. Pada dosis iradiasi 0 Gy dengan konsentrasi genangan kontrol (sebelum genangan) dan 250\% (sesudah genangan) ditemukan 7 pita protein. Pada dosis iradiasi 25 Gy dengan konsentrasi genangan kontrol (sesudah genangan) ditemukan 6 pita protein. Pada dosis iradiasi 25 Gy dengan konsentrasi genangan 250\% (sesudah genangan), dosis iradiasi 75 Gy dengan konsentrasi genangan kontrol (sesudah genangan), dan dosis iradiasi 100 Gy dengan konsentrasi genangan kontrol (sesudah genangan) ditemukan 5 pita protein. Pada dosis iradiasi 50 Gy, 75 Gy, dan 100 Gy dengan konsentrasi genangan $250 \%$ (sesudah genangan) ditemukan 3 pita protein. Hal ini membuktikan bahwa dosis iradiasi dan konsentrasi genangan mempengaruhi jumlah pita protein yang dihasilkan.

Tabel 4

Berat Molekul Protein Kedelai Varietas Grobogan dengan SDS-PAGE.

\begin{tabular}{|c|c|c|c|c|c|c|c|c|c|c|c|}
\hline $\begin{array}{c}\text { Berat } \\
\text { Molekul Pita } \\
\text { Protein (kDa) }\end{array}$ & A & B & $\mathrm{C}$ & D & $\mathrm{E}$ & $\mathrm{F}$ & G & $\mathrm{H}$ & I & $\mathbf{J}$ & K \\
\hline 260 & $\sqrt{ }$ & - & - & - & - & - & - & - & - & - & - \\
\hline 259 & - & - & - & - & - & - & - & - & - & - & $\sqrt{ }$ \\
\hline 256 & - & - & $\sqrt{ }$ & - & - & - & - & - & - & - & - \\
\hline 229 & - & $\sqrt{ }$ & - & - & - & - & - & - & - & - & - \\
\hline 226 & - & - & - & - & - & - & - & - & - & $\sqrt{ }$ & - \\
\hline 224 & - & - & - & - & - & - & - & $\sqrt{ }$ & - & - & - \\
\hline 216 & - & - & - & - & - & - & - & - & $\sqrt{ }$ & - & - \\
\hline 193 & - & - & - & - & - & - & $\sqrt{ }$ & - & - & - & - \\
\hline 190 & - & - & - & $\sqrt{ }$ & - & - & - & - & - & - & - \\
\hline 183 & - & - & - & - & $\sqrt{ }$ & $\sqrt{ }$ & - & - & - & - & - \\
\hline 115 & - & - & $\sqrt{ }$ & - & - & - & - & - & - & - & - \\
\hline 114 & - & $\sqrt{ }$ & - & - & - & - & - & - & - & - & - \\
\hline 111 & - & - & - & - & - & - & - & - & - & - & $\sqrt{ }$ \\
\hline 109 & - & - & - & - & - & - & - & - & - & $\sqrt{ }$ & - \\
\hline 102 & - & - & - & - & - & - & - & $\sqrt{ }$ & $\sqrt{ }$ & - & - \\
\hline 80 & $\sqrt{ }$ & - & - & - & - & - & - & - & - & - & - \\
\hline 75 & - & $\sqrt{ }$ & - & - & - & - & - & - & - & - & - \\
\hline 72 & - & - & $\sqrt{ }$ & - & - & - & - & - & - & - & - \\
\hline 62 & - & - & - & - & - & - & - & - & $\sqrt{ }$ & - & - \\
\hline 59 & - & - & - & - & - & - & - & $\sqrt{ }$ & - & $\sqrt{ }$ & - \\
\hline 55 & - & $\sqrt{ }$ & - & - & - & - & $\sqrt{ }$ & - & - & - & - \\
\hline 53 & - & - & $\sqrt{ }$ & - & - & - & - & - & - & - & $\sqrt{ }$ \\
\hline 51 & - & - & - & - & $\sqrt{ }$ & - & - & - & - & - & - \\
\hline 48 & - & - & - & $\sqrt{ }$ & - & - & - & - & - & - & - \\
\hline 45 & - & - & - & - & - & $\sqrt{ }$ & - & - & - & - & - \\
\hline 39 & - & - & $\sqrt{ }$ & - & - & - & - & - & - & - & - \\
\hline 37 & - & - & - & - & $\sqrt{ }$ & - & - & - & - & - & - \\
\hline 35 & $\sqrt{ }$ & - & - & - & - & - & - & - & - & - & - \\
\hline 33 & - & - & - & - & - & $\sqrt{ }$ & - & - & - & - & - \\
\hline 29 & $\sqrt{ }$ & - & - & - & - & - & - & - & - & - & - \\
\hline 28 & - & $\sqrt{ }$ & - & - & - & - & - & - & - & - & - \\
\hline 26 & - & - & - & - & - & $\sqrt{ }$ & - & - & - & - & - \\
\hline 24 & $\sqrt{ }$ & - & - & $\sqrt{ }$ & - & - & - & - & - & - & - \\
\hline 23 & - & $\sqrt{ }$ & $\sqrt{ }$ & - & - & - & - & - & - & - & - \\
\hline 21 & - & - & - & - & $\sqrt{ }$ & - & - & - & - & - & - \\
\hline 20 & - & - & - & $\sqrt{ }$ & - & $\sqrt{ }$ & - & - & - & - & - \\
\hline 15 & - & - & - & - & - & $\sqrt{ }$ & - & - & - & - & - \\
\hline 14 & $\sqrt{ }$ & $\sqrt{ }$ & - & - & - & - & - & - & - & - & - \\
\hline 13 & $\sqrt{ }$ & $\sqrt{ }$ & $\sqrt{ }$ & - & - & $\sqrt{ }$ & - & $\sqrt{ }$ & - & $\sqrt{ }$ & - \\
\hline 12 & - & - & - & $\sqrt{ }$ & $\sqrt{ }$ & $\sqrt{ }$ & - & $\sqrt{ }$ & - & - & - \\
\hline 11 & - & - & - & $\sqrt{ }$ & - & - & $\sqrt{ }$ & - & - & $\sqrt{ }$ & - \\
\hline
\end{tabular}

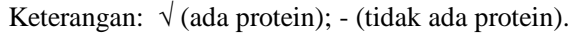

Analisis profil protein terlihat pita protein dengan mobilitas terendah sampai tertinggi terletak pada berat molekul 260-11 $\mathrm{kDa}$ (Tabel 4). Pita protein yang hanya dimiliki dosis iradiasi 0 Gy dengan konsentrasi genangan kontrol (sebelum genangan) adalah pita $260,80,35$, dan $29 \mathrm{kDa}$. Pita protein yang hanya dimiliki dosis iradiasi 0 Gy dengan konsentrasi genangan kontrol (sesudah genangan) adalah pita 229, 114, 79, dan 28 $\mathrm{kDa}$. Pita protein yang hanya dimiliki dosis iradiasi $0 \mathrm{~Gy}$ dengan konsentrasi genangan $250 \%$ (sesudah genangan) 
adalah pita $256,115,72$, dan $39 \mathrm{kDa}$. Pita protein yang hanya dimiliki dosis iradiasi 25 Gy dengan konsentrasi genangan kontrol (sesudah genangan) adalah pita 190 dan $48 \mathrm{kDa}$. Pita protein yang hanya dimiliki dosis iradiasi 25 Gy dengan konsentrasi genangan $250 \%$ (sesudah genangan) adalah pita 51,37 , dan $21 \mathrm{kDa}$. Pita protein yang hanya dimiliki dosis iradiasi 50 Gy dengan konsentrasi genangan kontrol (sesudah genangan) adalah pita $45,33,26$, dan $15 \mathrm{kDa}$. Pita protein yang hanya dimiliki dosis iradiasi 50 Gy dengan konsentrasi genangan 250\% (sesudah genangan) adalah pita $193 \mathrm{kDa}$. Pita protein yang hanya dimiliki dosis iradiasi 75 Gy dengan konsentrasi genangan kontrol (sesudah genangan) adalah pita $224 \mathrm{kDa}$. Pita protein yang hanya dimiliki dosis iradiasi $75 \mathrm{~Gy}$ dengan konsentrasi genangan $250 \%$ (sesudah genangan) adalah pita 216 dan $62 \mathrm{kDa}$. Pita protein yang hanya dimiliki dosis iradiasi 100 Gy dengan konsentrasi genangan kontrol (sesudah genangan) adalah pita 226 dan $109 \mathrm{kDa}$. Pita protein yang hanya dimiliki dosis iradiasi $100 \mathrm{~Gy}$ dengan konsentrasi genangan 250\% (sesudah genangan) adalah pita 229 dan 111 $\mathrm{kDa}$.

Karakterisasi menggunakan kisaran berat molekul dilakukan karena pita-pita yang dihasilkan dari hasil SDS-PAGE beragam dan saling berdekatan. Pita-pita protein yang saling berdekatan (doublet) mengindikasikan bahwa protein tersebut memiliki kesamaan jumlah asam-asam amino, namun salah satu diantaranya memiliki ekstra residu asam amino sehingga menyebabkan posisi pitanya sedikit berbeda [33]. Pita yang terletak pada bagian atas menunjukkan berat molekul yang besar dibandingkan dengan pita yang berada di bawahnya karena molekul yang lebih kecil dari pori gel dapat bergerak dengan mudah di dalam gel, sedangkan molekul yang lebih besar hampir tidak bergerak. Hal itu juga menjadi alasan tersebarnya keberadaan pita-pita protein yang muncul pada gel akrilamid [34].

Daun memainkan peran utama dalam mengangkut unsurunsur penting dan air dari akar ke bagian aerial. Sebagian besar protein yang teridentifikasi terlibat dalam produksi energi dan metabolisme primer/sekunder pada jaringan daun. Pada tumbuhan tingkat tinggi, daun mewakili organ yang sangat terspesialisasi terutama terlibat dalam fotosintesis. Tingkat dan aktivitas fotosintesis sangat tergantung pada perkembangan dan usia daun, dan ini juga berkorelasi dengan akumulasi protein seperti ribulosa-1,5-bifosfat karboksilase/oksigenase ( $R u B i s C O)$ dan protein lainnya yang berhubungan dengan fotosintesis. RuBisCO memiliki fungsi ganda: bertindak sebagai karboksilase yang memediasi fotosintesis asimilasi $\mathrm{CO}_{2}$ dan sebagai oksigenase mengkatalisis tahap pertama dari jalur fotorespirasi. Cekaman genangan menginduksi pembentukan reactive oxygen species (ROS) yang pada akhirnya menyebabkan degradasi subunit dari RuBisCO dan RuBisCO activase [31].

Genangan menyebabkan hipoksia yaitu berkurangnya konsentrasi oksigen di dalam tanah dan jika genangan berkepanjangan secara progresif menyebabkan anoksia (ketiadaan oksigen). Karena $\mathrm{O}_{2}$ bertindak sebagai akseptor elektron terminal dalam transpor elektron mitokondria, oleh karena itu, menipisnya $\mathrm{O}_{2}$ menyebabkan penurunan rasio
ATP/ADP yang menggeser metabolisme sel menjadi fermentasi anaerobik untuk menghasilkan ATP dan $\mathrm{NADP}^{+}$ untuk mempertahankan kebutuhan energi dan dengan demikian memperpanjang kelangsungan hidup. Produksi ROS meningkat di bawah berbagai stres. Untuk melindungi sel dari efek merugikan ROS, jaringan tanaman memiliki ROS scavenging enzymes yaitu superoxide dismutase (SOD), catalase (CAT), peroxidases ( $\mathrm{POX}$ ) dan polyphenol oxidase (PPO), dan jaringan massa molekul rendah antioksidan non enzimatik seperti askorbat, glutathion, senyawa fenolik dan tokoferol. Untuk menetralkan ROS atau meregenerasi bentuk antioksidan aktif; enzim seperti ascorbate peroxidase (APX), dehydroascorbate reductase (DHAR), glutathione reductase $(G R)$ pada dasarnya diperlukan [35].

\section{KESIMPULAN}

Berdasarkan hasil penelitian dapat disimpulkan bahwa dosis iradiasi dan konsentrasi genangan memberikan respon yang berbeda-beda pada setiap perlakuan. Pengamatan morfologi dengan parameter viabilitas dan vigoritas benih, tinggi tanaman, dan luas daun paling optimal saat diberikan dosis iradiasi $0 \mathrm{~Gy}, 25 \mathrm{~Gy}$, dan $50 \mathrm{~Gy}$ dengan konsentrasi genangan kontrol. Sedangkan terendah saat diberikan dosis iradiasi 75 Gy dan 100 Gy dengan konsentrasi genangan 250\%. Analisis profil protein dengan SDS-PAGE didapatkan bahwa pita protein dengan mobilitas terendah sampai tertinggi terletak pada berat molekul 260-11 kDa. Hal tersebut ditunjukkan dengan perbedaan jumlah pita protein, berat molekul pita protein, dan ketebalan pita protein yang dihasilkan.

\section{DAFTAR PUSTAKA}

[1] M. Firdaus, "Self Sufficiency Outlook of Indonesia Soybean on the Era of Trade Liberalization," J. Basic Appl. Sci. Res., vol. 5, no. 1, pp. 105-110, 2015.

[2] and C. A. S. Lamptey, B. D. K. Ahiabor, S. Yeboah, "Response of Soybean (Glycine max) to Rhizobial Inoculation and Phosphorus Application," J. Exp. Biol. Agric. Sci., vol. 2, no. 1, pp. 72-77, 2014.

[3] R. Aldillah, "Proyeksi Produksi dan Konsumsi Kedelai Indonesia," J. Ekon. Kuantitatif Terap., vol. 8, no. 1, pp. 9-23, 2015.

[4] and S. K. M. Oh, Y. Nanjo, "Gel-free Proteomic Analysis of Soybean Root Proteins Affected by Calcium Under Flooding Stress," Front. Plant Sci., vol. 5, no. 559, pp. 1-15, 2014.

[5] and I. J. L. Y. H. Kim, S. J. Hwang, M. Waqas, A. L. Khan, J. H. Lee, J. D. Lee, H. T. Nguyen, "Comparative Analysis of Endogenous Hormones Level in Two Soybean (Glycine max L.) Lines Differing in Waterlogging Tolerance," Front. Plant Sci., vol. 6, no. 714, pp. 1-13, 2015.

[6] dan M. M. A. R. T. Hapsari, "Peluang Perakitan dan Pengembangan Kedelai Toleran Genangan," J. Litbang Pertan., vol. 29, no. 2, pp. 50-57, 2010.

[7] dan T. B. S. V. S. Fatimah, "Respon Karakter Fisiologis Kedelai (Glycine max L.) Verietas Grobogan terhadap Cekaman Genangan," J. Sains dan Seni ITS, vol. 5, no. 2, pp. E71-E77, 2016.

[8] dan M. M. A. W. Rahajeng, "Varietas Kedelai Umur Genjah," Bul. Palawija, vol. 26, pp. 91-100, 2013.

[9] dan R. Z. N. L. E. Farida, D. Saptadi, "Uji Vigor dan dan Viabilitas Benih Dua Klon Karet (Hevea brasiliensis Muell Arg.) Pada Beberapa Periode Penyimpanan," J. Produksi Tanam., vol. 5, no. 3, pp. 484-492, 2017.

[10] T. B. Saputro, "Multiplikasi Tunas Pada Mikoropropagasi Tanaman Transgenik Anggrek (Phalaenopsis amabilis L.) Blume Pembawa 
35S::KNAT1 Pada Media Tanpa Fitohormon,” UGM, 2012.

[11] dan M. D. Y. Bramasto, Putri, P. K. Zanzibar, "Pemanfaatan Teknik Irradiasi Sinar Gamma Untuk Meningkatkan Viabilitas Benih Sengon," J. Hutan Trop., vol. 4, no. 1, pp. 14-20, 2016.

[12] dan D. J. S. M. Zanzibar, Megawati, E. Pujiastuti, "Iradiasi Sinar Gamma (60Co) untuk Meningkatkan Perkecambahan dan Pertumbuhan Bibit Tembesu (Fagraea fragrans Roxb.)," J. Penelit. Hutan Tanam., vol. 12, no. 3, pp. 165-174, 2015.

[13] and W. J. R. Q. H. Li, S. X. Wang, Y. M. Zhao, J. Xu, T. T. Gao, "Irradiation Dose and Effect on Germination and Growth of Desert Shrub Nitraria tangutorum Borb. with Two Gamma Irradiation Modes," Pak. J. Bot, vol. 44, no. 2, pp. 661-666, 2012.

[14] dan T. B. S. P. L. Nurrachmamila, "Analisis Daya Perkecambahan Padi (Oryza sativa L.) Varietas Bahbutong Hasil Iradiasi," J. Sains dan Seni ITS, vol. 6, no. 2, pp. E17-E21, 2017.

[15] and N. T. M. K. Lesilolo, J. Patty, "Penggunaan Desikan Abu dan Lama Simpan Terhadap Kualitas Benih Jagung (Zea mays L.) pada Penyimpanan Ruang Terbuka," Agrologia, vol. 1, no. 1, pp. 51-59, 2012.

[16] C. Jia and A. Li, "Effect of gamma radiation on mutant induction of Fagopyrum dibotrys Hara," Photosynthetica, vol. 46, pp. 363-369, 2008.

[17] dan T. B. S. I. Prabhandaru., "Respon Perkecambahan Benih Padi (Oryza sativa L.) Varietas Lokal SiGadis Hasil Iradiasi Sinar Gamma," J. Sains dan Seni ITS, vol. 6, no. 2, pp. E48-E52, 2017.

[18] S. Utami, "Uji Viabilitas dan Vigoritas Benih Padi Lokal Ramos Adaptif Deli Serdang dengan Berbagai Tingkat Dosis Irradiasi Sinar Gamma di Persemaian," Agrium, vol. 18, no. 2, pp. 158-161, 2013.

[19] and M. S. Jan, T. Parween, T. O. Siddiqi, "Effect of Gamma Radiation on Morphological, Biochemical, and Physiological Aspects of Plants and Plant Products," Environ. Rev., vol. 20, pp. 17-39, 2012.

[20] dan I. G. A. K. G. N. Sutapa, "Efek Induksi Mutasi Radiasi Gamma 60Co Pada Pertumbuhan Fisiologis Tanaman Tomat (Lycopersicon esculentum L.)," J. Keselam. Radiasi dan Lingkung., vol. 1, no. 2, pp. 5-11, 2016.

[21] and M. N. N. F. A. Minisi, M. E. El-mahrouk, M. E. F. Rida, "Effects of Gamma Radiation on Germination, Growth Characteristics and Morphological Variations of Moluccella laevis L,” Am. J. Agric. Environ. Sci., vol. 13, no. 5, pp. 696-704, 2013.

[22] dan L. K. D. S. R. Anshori, S. I. Aisyah, "Induksi Mutasi Fisik dengan Iradiasi Sinar Gamma pada Kunyit (Curcuma domestica Val.)," J. Hortik. Indones., vol. 5, no. 3, pp. 84-94, 2014.
[23] J. and T. D. C. M. B., "Response and Adaptation by Plants to Flooding Stress," Ann. Bot., vol. 96, no. 4, pp. 501-505, 2005.

[24] dan T. B. S. E. A. Rohmah, "Analisis Pertumbuhan Tanaman Kedelai (Glycine max L.) Varietas Grobogan Pada Kondisi Cekaman Genangan," J. Sains dan Seni ITS, vol. 5, no. 2, pp. E29E33, 2016.

[25] I. K. Sato, T., Harada T, "Stimulation of glycolysis in anaerobic elongation of pondweed (Potamogeton distinctus) turion," J. Exp. Bot, vol. 53, pp. $1847-56,2002$.

[26] H. Kende, "Deepwater Rice: A Model Plant to Study Stem Elongation," Plant Physiol, vol. 118, pp. 1105-1110, 1998.

[27] E. M. S. and N. J. T B Saputro, K T Purwani, V S Fatimah, "The tolerance improvement of local soybean in waterlogging condition through the combination of irradiation and in vivo selection," $J$. Phys. Conf. Ser., 2018.

[28] A. W. I. dan F. Y. Wicaksono, "Perbandingan Pengukuran Luas Daun Kedelai dengan Metode Gravimetri, Regresi dan Scanner," $J$. Kultiv., vol. 16, no. 3, pp. 425-429, 2017.

[29] A. S. J. H. S. Meliala, N. Basuki, "Pengaruh Iradiasi Sinar Gamma Terhadap Perubahan Fenotipik Tanaman Padi Gogo (Oryza sativa L.)," J. Produksi Tanam., vol. 4, no. 7, pp. 585-594, 2016.

[30] L. M. M. dan T. Ginting, "Pertumbuhan dan Hasil Kedelai (Glycine $\max ($ L) Merr) Akibat Tinggi Muka Air Tanah pada Beberapa Stadia Pertumbuhan," vol. 19, no. 1, pp. 1-13, 2010.

[31] S. K. and Z. Hossain, "Organ-Specific Proteome Analysis for Identification of Abiotic Stress Response Mechanism in Crop," Front. Plant Sci., vol. 4, no. 71, pp. 1-9, 2013.

[32] and B. H. L. N. Ahsan, D. G. Lee, S. H. Lee, K. W. Lee, J. D. Bahk, "A Proteomic Screen and Identification of WaterloggingRegulated Proteins in Tomato Roots," Plant Soil, vol. 295, pp. 3751, 2007.

[33] dan P. L. P. S. A. D. Wibowo, M. T. Suhartono, "Fraksionasi dan Penentuan Profil Protein Bungkil Kelapa dengan SDS-PAGE," $J$. Teknol. dan Ind. Pangan, vol. 23, no. 1, pp. 69-74, 2012.

[34] dan D. S. M. D. Masyitoh, I. D. A. R. Dewanti, "Analisis Profil Protein Ekstrak Aquades dan Etanol Daun Mimba (Azadirachta indica A. Juss) dengan Metode SDS-PAGE," e-Jurnal Pustaka Kesehat., vol. 4, no. 3, pp. 533-539, 2016.

[35] A. J. and J. P. Srivastava, "Changes in Reactive Oxygen Scavenging Systems and Protein Profiles in Maize Roots in Response to Nitric Oxide Under Waterlogging Stress," Indian J. Biochem. Biophys., vol. 55, pp. 26-33, 2018. 